KOŚCIÓŁ I PRAWO 10(23) 2021, nr 2, s. 225-238

DOI: https://doi.org/10.18290/kip21102.15

\title{
Weronika Woźna-Burdziak
}

\section{REKLAMA A OBRAZA UCZUĆ RELIGIJNYCH}

\section{WPROWADZENIE}

Badania naukowe wskazują, że z pierwszymi przejawami aktywności ludzkiej, jakie wiążą się z szeroko rozumianą reklamą, mamy do czynienia już w antyku, a konkretnie w starożytnym Egipcie [Wiszniewska 2019, 1]. Oczywiście ówczesna reklama nie przypominała w żaden sposób obecnej, choć jak twierdzą historycy, w dalszym ciągu to jedno z najstarszych działań o charakterze gospodarczym [Starzyńska 2015, 275]. Ten ostatni czynnik jest, co warto podkreślić, swoiście niezmienny - także i dziś, reklama nieustannie przyczynia się do nieprzerwanego rozwoju gospodarczego. Upływ lat wciąż zdaje się potwierdzać i utrwalać powszechnie znane powiedzenie: „reklama dźwignią handlu”. Ciężko, przy obecnym poziomie konkurencji gospodarczej, tak w ujęciu lokalnym, jak i globalnym znaleźć dziedzinę działalności gospodarczej, w której tego typu rodzaj rywalizacji nie występuje. Reklama stała się narzędziem komunikacji między przedsiębiorcą a konsumentem. Wiadome jest, że im więcej potencjalnych konsumentów zetknie się z reklamą, tym bardziej rosną szanse, że przełoży się to na zyski przedsiębiorcy. Współczesna reklama przybiera najróżniejsze formy i dotyka niemalże każdej sfery życia gospodarczego (a szerzej społecznego). Jest wszechobecna ze względu na ciągle rosnącą liczbę

MGr Weronika WoźNA-BuRdZiAK - doktorant, Wydział Prawa i Administracji, Uniwersytet Szczeciński; adres do korespondencji: ul. Narutowicza 17A, 70-240 Szczecin, Polska; e-mail: weronika.wozna-burdziak@usz.edu.pl; https://orcid.org/0000-0002-12716028 
przedsiębiorców reklamujących swoje produkty/usługi, co za tym idzie konsumenci są coraz bardziej świadomi jej oddziaływania ${ }^{1}$.

Aby reklama spełniła swoje zadanie reklamodawcy posuwają się do coraz bardziej kontrowersyjnych i zaskakujących rozwiązań, odnosząc się w reklamie do niemal wszystkich aspektów życia. Niekiedy reklamy dotykają w swojej tematyce sfery duchowości czy wiary, i o ile samo poruszenie tej tematyki w reklamie nie jest zakazane, o tyle sposób jej prezentacji należy poddać analizie prawnej, w szczególności zważywszy na fakt, że może on naruszać przepisy prawa.

Zawarte $\mathrm{w}$ niniejszym opracowaniu badania dotyczyć będą kwestii obrazy uczuć religijnych poprzez reklamę. W pierwszej kolejności zdefiniowane zostanie pojęcie reklamy. Powyższe jest o tyle utrudnione, bowiem ustawodawca nie zawarł w żadnym akcie normatywnym wyczerpującej definicji przedmiotowego pojęcia. Niniejszy problem dotyczy również obrazy uczuć religijnych, bowiem ustawodawca nie zdefiniował w sposób wyczerpujący przywołanego zagadnienia ani też ich obrazy. W związku z tym, że uczucia religijne dla bardzo wielu osób są niezwykle ważne, kolejnym punktem opracowania będzie próba zdefiniowania pojęcia uczuć religijnych oraz wskazanie, co oznacza ich obraza. Powyższe doprowadzić ma do realizacji podstawowego celu badawczego opracowania, jakim jest próba odpowiedzi na pytanie: czy reklama może obrażać uczucia religijne?

\section{POJĘCIE REKLAMY - ANALIZA WSTĘPNA}

W polskim ustawodawstwie próżno szukać jednej kompletnej definicji reklamy. W obiegu prawnym funkcjonuje bowiem bardzo wiele aktów normatywnych, które w swojej treści definiują przedmiotowe pojęcie, oczywiście w odwołaniu do zakresu merytorycznego danego dokumentu. Niniejsze opracowanie dotyczy problemu obrazy uczuć religijnych w reklamie, w związku z czym konieczne jest wykreowanie jak najbardziej uniwersalnej definicji reklamy.

Punktem wyjścia do zbudowania ogólnej definicji reklamy w pierwszej kolejności musi być przywołanie aktów normatywnych, które w swoim za-

\footnotetext{
${ }^{1}$ Wyrok Sądu Apelacyjnego w Warszawie z dnia 4 kwietnia 2013 r., sygn. akt I ACa 1167/12, http://orzeczenia.waw.sa.gov.pl/content/\$N/154500000000503_I_ACa_001167 _2012_Uz_2013-04-04_002 [dostęp: 14.11.2021].
} 
kresie merytorycznym definiują pojęcie reklamy. Nie jest oczywiście możliwe - ze względu na ograniczony zakres niniejszego opracowania - wskazanie wszystkich aktów normatywnych, które owe pojęcie definiują, dlatego też autor wskazał na ustawy, które określają reklamę w sposób bardzo szeroki, nie ograniczając się tym samym tylko do wybranych rodzajów reklamy, czy rodzajów produktów/usług, których ta reklama dotyczy. Tym samym, co z metodologicznego punktu widzenia należy wyraźnie wskazać, $\mathrm{w}$ niniejszym opracowaniu pominięte zostaną akty normatywne definiujące reklamę w odniesieniu do konkretnej gałęzi działalności gospodarczej. Przywołanie tych najbardziej szerokich definicji zawartych w aktach normatywnych posłuży do skonstruowania jednej złożonej, acz uniwersalnej definicji, która następnie zostanie wykorzystana do rozważań przedstawionego problemu.

Legalną definicję reklamy można w pierwszej kolejności znaleźć w ustawie o Radiofonii $i$ Telewizji ${ }^{2}$, zgodnie z którą „reklamą jest przekaz handlowy, pochodzący od podmiotu publicznego lub prywatnego, w związku $\mathrm{z}$ jego działalnością gospodarczą lub zawodową, zmierzający do promocji sprzedaży lub odpłatnego korzystania z towarów lub usług; reklamą jest także autopromocja". Prezentowana definicja jest bardzo szeroka, nie zamyka się na konkretny rodzaj reklamy, jak np. reklama telewizyjna, natomiast ustawodawca położył $\mathrm{w}$ niej nacisk na powiązanie reklamy z działalnością gospodarczą bądź zawodową reklamodawcy [Niewęgłowski 2021]. Ponadto poza powiązaniem $\mathrm{z}$ działalnością gospodarczą nacisk położono również na zysk reklamodawcy, poprzez wskazanie na odpłatne korzystanie z usług czy towarów przez potencjalnych konsumentów. Definicja reklamy wyrażona w RTVU, nie odnosi się do przekazów o charakterze społecznym czy np. spotów wyborczych. Bowiem istotą reklamy ma być jej gospodarczy charakter, odziaływanie na konsumenta, który odpłatnie będzie chciał korzystać z reklamowanych towarów czy usług [Modrzejewska 2020]. Mimo, iż przytoczona definicja wprost wskazuje, czym jest reklama, to nie wyczerpuje ona $\mathrm{w}$ pełni prawnych aspektów dotyczących omawianego pojęcia [Nowińska 2005].

Kolejne dwa akty normatywne analizowane poniżej nie definiują pojęcia reklamy w taki sposób, w jaki dokonano tego w RTVU, jednak odnoszą

\footnotetext{
${ }^{2}$ Ustawa z dnia 29 grudnia 1992 o Radiofonii $i$ Telewizji, Dz. U. z 2020 r., poz. 805 z późn. zm. [dalej: RTVU].
} 
się do niej regulując kwestie z nią związane w odniesieniu do czynów nieuczciwej konkurencji oraz nieuczciwych praktyk rynkowych [Ślęzak 2011, 16]. Mimo braku wprost wyrażonych definicji zakres regulacji analizowanych dokumentów pozwolił na wypracowanie znaczenia pojęcia reklamy $\mathrm{w}$ doktrynie i orzecznictwie.

Pierwszym aktem, który w swojej treści wprost nie definiuje reklamy, jednak się do niej odnosi w bardzo szerokim znaczeniu jest ustawa o zwalczaniu nieuczciwej konkurencji ${ }^{3}$. Przywołany akt normatywny odmiennie od RTVU nie wskazuje wprost w sposób pozytywny, czym jest reklama, a definiuje ją przez pryzmat czynu nieuczciwej konkurencji. Ustawodawca, w przywołanym akcie normatywnym wskazuje, iż czynem nieuczciwej konkurencji jest m.in. zakazana reklama. Zakazaną reklamą jest natomiast np. reklama wprowadzająca w błąd, sprzeczna $\mathrm{z}$ dobrymi obyczajami, czy urągająca godności człowieka. W ZNKU ustawodawca wskazał działania czy zaniechania, które w reklamie mogą być uznane za czyny nieuczciwej konkurencji. Mowa o działaniach i zaniechaniach, bowiem analizując regulacje wyrażone w art. 16 ZNKU, wyraźnie widać, że naruszenia wskazanego artykułu można dopuścić się zarówno działaniem, jak i zaniechaniem. Najprościej można ukazać to na przykładzie reklamy wprowadzającej w błąd, bowiem w błąd można wprowadzić zarówno podając w przekazie reklamowym informacje obiektywnie nieprawdziwe, jak i nie podając jakiejś informacji, której brak w reklamie może wprowadzać w błąd [Modrzejewska 2020].

Jak już zaznaczono w ZNKU brak jest legalnej, wyrażonej wprost definicji reklamy, jednak doktryna i orzecznictwo przychodzą w tym zakresie z pomocą. W pierwszej kolejności należy przywołać jeden z wyroków Sądu Najwyższego, w którym wskazano, że na gruncie ZNKU za reklamę należy uznać każdy przekaz, zarówno o charakterze bezpośrednim, jak i pośrednim, który jest kierowany do potencjalnych konsumentów, a jego celem jest skłonienie odbiorców do zakupu danego towaru czy usługi. Co ważne SN pokreślił, że zachęta do zakupu nie musi być wyrażona wprost, aby można było mówić o reklamie ${ }^{4}$. Podobnie we wskazanej kwestii wypowiada się doktryna, wskazując, że regulacje dotyczące reklamy znajdujące się w ZNKU mają zastosowanie uniwersalne i dotyczą każdego przekazu, któ-

\footnotetext{
${ }^{3}$ Ustawa z dnia 16 kwietnia 1993 r. o zwalczaniu nieuczciwej konkurencji, Dz. U. z 2020 r., poz. 1913 [dalej: ZNKU].

${ }^{4}$ Wyrok Sadu Najwyższego - Izba Cywilna z dnia 26 stycznia 2006 r., sygn. akt V CSK 83/05, https://www.saos.org.pl/judgments/163982 [dostęp: 14.11.2021].
} 
rego celem jest wpłynięcie na decyzje zakupowe potencjalnych konsumentów [Mądry 2016].

Kolejnym aktem normatywnym, który odnosi się do pojęcia reklamy jest ustawa o przeciwdziałaniu nieuczciwym praktykom rynkowym ${ }^{5}$. Przywołany akt normatywny podobnie jak ZNKU nie definiuje w sposób otwarty pojęcia reklamy, natomiast klasyfikuje ją jako praktykę reklamową PNPR w swojej treści głównie skupia się na wskazaniu nieuczciwych praktyk rynkowych, które zostały przez ustawodawcę wymienione poprzez określenie konkretnych działań przedsiębiorców - tzw. czarna lista praktyk rynkowych [Namysłowska 2007]. Za nieuczciwą praktykę rynkową ustawodawca uznaje m.in. wprowadzenie w błąd, czy też nieuczciwą reklamę porównawczą. Należy zaznaczyć, że na gruncie PNPR reklama określana jest jako działanie przedsiębiorcy bezpośrednio związane z promocją, sprzedażą lub dostawą produktu do konsumentów [Wiewiórowska-Domagalska i Kunkiel-Kryńska 2019].

$\mathrm{Na}$ gruncie powyższych regulacji prawnych możliwym i zarazem zasadnym jest podjęcie próby stworzenia definicji reklamy, jaka wykorzystana zostanie w dalszej części opracowania. Tak skonstruowana definicja stanowić będzie narzędzie realizacji założonego celu badawczego. Powyższe egzemplifikacje definicji zawartych w aktach normatywnych, a także zasygnalizowane stanowiska doktryny i orzecznictwa pozwalają przyjąć, iż na potrzeby niniejszego opracowania reklama definiowana będzie jako rodzaj przekazu, za pośrednictwem którego przedsiębiorca chce zaprezentować swój produkt czy usługę jak najszerszemu gronu odbiorców/konsumentów. Podstawowym celem reklamy jest osiągnięcie celu gospodarczego, czyli przyczynienie się do zwiększenia popytu na oferowane przez przedsiębiorcę dobra. Należy zgodzić się z poglądem, że w najszerszym rozumieniu pojęcia reklamy ma ona służyć rozpowszechnianiu, popularyzacji informacji, nie tylko o samych produktach czy usługach, ale też o danym przedsiębiorcy [Chałubińska-Jentkiewicz i Karpiuk 2015]. W doktrynie podkreśla się również, że reklama - choć nie musi być bezpośrednia - charakteryzuje ją celowość. Przedsiębiorca reklamuje siebie, bądź swoje pro-

\footnotetext{
${ }^{5}$ Ustawa z dnia 23 sierpnia 2007 r. o przeciwdziałaniu nieuczciwym praktykom rynkowym, Dz. U. z 2017 r., poz. 2070 [dalej: PNPR].

${ }^{6}$ Wyrok Sądu Apelacyjnego w Warszawie z dnia 15 marca 2017 r., sygn. akt VI ACa 1864/15, http://orzeczenia.waw.sa.gov.pl/content/\$N/154500000003003_VI_ACa_ 001864_2015_Uz_2017-03-15_002 [dostęp: 14.11.2021].
} 
dukty po to, ażeby wpłynąć na potencjalnych konsumentów i oddziaływać na ich decyzje [Walczak 2001, 551n.]. W jednym z wyroków SN wskazał, że nie jest istotne, aby pod wpływem reklamy konsument zdecydował się np. na zakup reklamowanego produktu. Istotny jest sam zamiar, jaki przyświecał przedsiębiorcy, kreując daną reklamę. Natomiast to, czy reklama spełniła swoje zadanie można zweryfikować w odwołaniu do opinii odbiorcy przekazu? ${ }^{7}$ Podkreślenia wymaga również fakt, iż należy odróżnić reklamę od zwykłej informacji, bowiem aby przekaz można było określić mianem reklamy musi on w swojej treści zawierać elementy zachęcające do nabycia danego produktu czy usługi bądź być formą promocji przedsiębiorcy. Te właśnie elementy w sposób istotny odróżniają reklamę od innych przekazów, podkreślając tym samym jej gospodarczy cel. Ponadto w szerokim rozumieniu definicji reklamy, reklama może przybrać każdą z możliwych form - może być reklamą telewizyjną, internetową czy radiową.

\section{OBRAZA UCZUĆ RELIGIJNYCH - ANALIZA WSTĘPNA}

W pierwszej kolejności należy wskazać, który z polskich aktów normatywnych reguluje kwestie związane $\mathrm{z}$ obrazą uczuć religijnych. Obraza uczuć religijnych została przez polskiego ustawodawcę uregulowana w Kodeksie karnym ${ }^{8}$, jako przestępstwo przeciwko wolności sumienia i wyznania. W myśl art. $196 \mathrm{KK}$ „Kto obraża uczucia religijne innych osób, znieważając publicznie przedmiot czci religijnej lub miejsce przeznaczone do publicznego wykonywania obrzędów religijnych, podlega grzywnie, karze ograniczenia wolności albo pozbawienia wolności do lat 2 ".

Ustawodawca sklasyfikował obrazę uczuć religijnych jako przestępstwo, nie definiując jednak samego pojęcia uczuć religijnych. Dlatego też aby móc przejść do dalszej analizy, w pierwszej kolejności należy, z pomocą doktryny i orzecznictwa zbudować przedmiotową definicję. Jak wynika z przywołanej regulacji, zakresem przedmiotowym przestępstwa obrazy uczuć religijnych jest przedmiot czci religijnej lub miejsce, w którym wykonywane są obrzędy religijne. Ustawodawca wskazał zatem na elementy

\footnotetext{
${ }^{7}$ Wyrok Sądu Najwyższego z dnia 14 stycznia 1997 r., sygn. akt I CKN 52/96, OSNC 1997, nr 6-7, poz. 78.

${ }^{8}$ Ustawa z dnia 6 czerwca 1997 r. Kodeks karny, Dz. U. z 2020 r., poz. 1444 z późn. zm. [dalej: KK].
} 
materialne [Filar i Berent 2016]. Należy zaznaczyć, że chodzi tu m.in. o świątynie czy przedmioty materialne służące do obrzędów wiary. Analizowaną regulacją nie jest objęty podmiot kultu, np. bóstwo [Budyn-Kulik 2014, 102]. Choć w powyższym zakresie pojawiają się również głosy odmienne wskazujące, że przedmiot czci religijnej należy traktować szeroko, również z odwołaniem do bóstwa czy Boga [Cebula 2012, 294; KozłowskaKalisz 2015; Tryka 2017, 73].

Należy zgodzić się ze stanowiskiem judykatury, iż obraza uczuć religijnych może przybrać każdą z możliwych form, może być dokonana w przekazie filmowym, za pośrednictwem zdjęć, mowy czy pisma9. Warto zaznaczyć, że w odniesieniu do obrazy uczuć w doktrynie dominuje pogląd, że występku tego można dopuścić się tylko umyślnie w zamiarze bezpośrednim, jak i ewentualnym ${ }^{10}$ [Cebula 2012, 294]. W doktrynie występuje jednak niejasność co do ilości osób, których uczucia religijne muszą zostać obrażone, aby można było mówić o zastosowaniu art. $196 \mathrm{KK}$. Część doktryny wskazuje, że aby doszło do obrazy uczuć religijnych skutek musi dotyczyć co najmniej dwóch osób [Piórkowska-Flieger 2016]. Wynika to z użycia przez ustawodawcę liczby mnogiej w analizowanej regulacji, tj. „innych osób”. Inni przedstawiciele doktryny uważają jednak, że ze względu na fakt, iż przedmiotowe przestępstwo ma charakter skutkowy, to dla wypełnienia jego znamion nie ma znaczenia liczba osób, której uczucia zostały obrażone, wystarczy zatem, aby skutek dotyczył jednej osoby [Zgoliński 2020]. W odniesieniu do samej skutkowości przestępstwa również dochodzi do rozbieżności, bowiem część doktryny wskazuje, iż przestępstwo to ma charakter bezskutkowy [Czepita i Pohl 2012]. Natomiast pojawiają się także poglądy wskazujące, iż konieczne jest, aby w odniesieniu do art. $196 \mathrm{KK}$ skutek ten wystąpił w postaci faktycznego odczucia obrazy uczuć u danej osoby [Kozłowska-Kalisz 2015].

Nie ulega jednak wątpliwości, że przestępstwo, o którym mowa, może zostać popełnione wyłącznie publicznie. Wynika to bezpośrednio z treści analizowanego przepisu. SN orzekł, że jeżeli ktoś znieważył np. przedmiot

\footnotetext{
${ }^{9}$ Wyrok Sadu Najwyższego z dnia 17 lutego 1993 r., sygn. akt II KRN 24/92, Wokanda 1993, nr 10, poz. 8, Lex.

${ }^{10}$ Uchwała Sadu Najwyższego - Izba Karna z dnia 29 października 2012 r., sygn. akt I KZP 12/12, http://www.sn.pl/sprawy/SitePages/Zagadnienia_prawne.aspx?Item $\mathrm{SID}=86-16544171-$ be1b-4089-b74b-413997467af2\&ListName=Zagadnienia_prawne\& Rok=2012 [dostęp: 14.11.2021].
} 
czci religijnej, natomiast nie zrobił tego publicznie, a jedynie ktoś inny to nagrał i umieścił $\mathrm{w}$ Internecie, to nie można mówić o wypełnieniu przez znieważającego przesłanek z art. $196 \mathrm{KK}^{11}$.

Kolejną niezwykle istotną kwestią dotyczącą obrazy uczuć religijnych jest ocena, względem kogo obraza może zostać dokonana, tzn. czy dopuszczenie się przestępstwa $\mathrm{z}$ art. $196 \mathrm{KK}$ powinno być oceniane przez pryzmat danej religii, czy też obiektywnie w oderwaniu niejako od danego wyznania. Oczywiste jest, że obraza uczuć religijnych będzie przez przedstawicieli danej wspólnoty religijnej odbierana subiektywnie. Natomiast ocena tego, czy doszło do popełnienia przestępstwa powinna zostać dokonana obiektywnie, jednak z uwzględnieniem, z jakiej grupy kulturowej wywodzi się osoba, której uczucia zostały obrażone [tamże]. Należy w tym miejscu zgodzić się z Trybunałem Konstytucyjnym, który wskazał, iż przestępstwa obrazy uczuć religijnych można dopuścić się tylko względem osoby, która wyznaje daną religię ${ }^{12}$.

Ostatnim elementem, który należy przeanalizować, jest próba wskazania desygnatów słowa „obrażać”. Według Słownika języka polskiego PWN obrażać, to inaczej m.in. „naruszyć słowem lub czynem jakieś normy, prawa lub wartości”13. Podobnie - z tym, że w odniesieniu do słowa „znieważenie" - wypowiedział się SN, wskazując, iż „oznacza on takie i tylko takie zachowanie, które według określonych przez normy kulturowo-obyczajowe i powszechnie przyjęte oceny stanowi wyraz pogardy"14.

\section{OBRAZA UCZUĆ RELIGIJNYCH W REKLAMIE}

Kontrowersyjność to jeden z najlepszych sposobów, aby posiąść uwage szerokiego grona odbiorców. Bardzo dobrze wiedzą o tym reklamodawcy, którzy chcąc zwiększyć popyt czy zaprezentować się na rynku sięgają po przeróżne metody, aby ich przekaz trafił do potencjalnych konsumentów.

\footnotetext{
${ }^{11}$ Postanowienie Sądu Najwyższego z dnia 5 marca 2015 r., sygn. akt II KK 274/14, http://www.sn.pl/sites/orzecznictwo/orzeczenia3/iii\%20kk\%20274-14.pdf [dostęp: 14.11. 2021].

${ }^{12}$ Wyrok Trybunału Konstytucyjnego z dnia 6 października 2015 r., sygn. akt SK 54/13, OTK-A 2015, nr 9, poz. 142, Lex.

${ }^{13}$ Zob. https:/sjp.pwn.pl/szukaj/obra\%C5\%BCa\%C4\%87.html [dostęp: 04.07.2021].

${ }^{14}$ Wyrok Sądu Najwyższego z dnia 21 marca 2001 r., sygn. akt II KKN 376/98, Lex nr 51376.
} 
Z całą pewnością za kontrowersyjne, a przynajmniej niekonwencjonalne, należy uznać reklamy, które w swojej treści odwołują się do kwestii wiary czy duchowości. A przecież sfera uczuć i wiary jest czymś niezwykle intymnym i indywidualnym. Poniżej w odwołaniu do definicji reklamy oraz obrazy uczuć religijnych autor dokonał rozważań na temat możliwości dopuszczenia się przestępstwa z art. $196 \mathrm{KK}$ w reklamie [Grębowiec 2010, 450].

Jak wynika z opracowanej na potrzeby niniejszego artykułu definicji reklamy, reklama powinna mieć charakter czysto gospodarczy, bowiem jej podstawowym celem jest zwiększenie zysków dla przedsiębiorcy, który reklamuje swoje usługi czy produkty. Obraza uczuć religijnych to natomiast przestępstwo popełnione przeciwko wolności sumienia i wyznania, którego celem jest znieważenie miejsca kultu czy przedmiotu czci religijnej. W odwołaniu do powyższego należy zadać sobie pytanie - czy reklama może obrażać uczucia religijne? Należy na nie z całym przekonaniem odpowiedzieć twierdząco, zwłaszcza mając na uwadze wcześniejsze rozważania. Jak już wskazano, reklama może przybrać każdą z możliwych form ${ }^{15}$, obrazy uczuć religijnych również można dopuścić się w każdej formie. Zatem można obrazić uczucia religijne w formie graficznej (np. bilbord), jak również słowem, np. w reklamowym spocie radiowym [Hypś 2021].

W art. $196 \mathrm{KK}$ ustawodawca wskazał, że obraza uczuć religijnych musi mieć charakter publiczny. Analizując to w odniesieniu do reklamy, również należy zgodzić się, iż reklama będzie spełniała ową przesłankę. Jej istotą jest bowiem dotarcie do jak najszerszego grona potencjalnych odbiorców. Jeżeli reklama ma postać np. spotu telewizyjnego, to $\mathrm{z}$ całą pewnością spełni przesłankę publicznego charakteru.

Ponadto w analizie obrazy uczuć religijnych wskazano na spór w doktrynie w odniesieniu do ilości osób pokrzywdzonych popełnieniem przestępstwa. Przy założeniu, że reklama ma trafić do jak najszerszego grona odbiorców należy stwierdzić, że również w tym przypadku nie byłoby problemu ze spełnieniem tejże przesłanki.

Powyżej przedstawiono teoretyczne możliwości naruszenia art. 196 KK poprzez reklamę, warto jednak dla dopełnienia całości wskazać na przykłady reklam, które dotykały sfery uczuć religijnych/wiary i przeanalizować je w odniesieniu do przestępstwa obrazy uczuć religijnych.

${ }^{15}$ Wyrok Naczelnego Sądu Administracyjnego z dnia 25 sierpnia 2016 r., sygn. akt II GSK 550/15, Lex nr 2636553. 
Komisja Etyki Reklamy ${ }^{16}$ za obrażającą uczucia religijne uznała reklamę, w której występuje roznegliżowana kobieta z różańcem na szyi. Komisja orzekła, iż połączenie nagości i przedmiotu służącego do obrzędów religijnych stanowi przejaw braku szacunku do określonej wiary ${ }^{17}$. Mając na względzie treść art. 196 KK należy zwrócić uwagę na fakt, iż w przywołanej reklamie pojawia się przedmiot, który jest w wierze katolickiej przedmiotem czci religijnej, zatem jedna z przesłanek regulacji KK została spełniona. Następnie należy się zastanowić, czy ukazanie różańca na szyi roznegliżowanej kobiety może obrażać uczucia religijne. Jak wcześniej wskazano, oceny takiej należy dokonywać obiektywnie, ale z odwołaniem do zasad danej wiary. $\mathrm{Z}$ całą pewnością dla katolika różaniec jest przedmiotem wiary o szczególnym charakterze i ukazanie go na szyi roznegliżowanej kobiety z podtekstem seksualnym, może dla osoby wyznającej wiarę katolicką powodować poczucie braku poszanowania dla jej przekonań religijnych. W omawianym przypadku spełniona została również przesłanka publicznego charakteru, bowiem reklama została udostępniona szerokiemu gronu odbiorców.

Zasadniczym przedmiotem badań zawartych w niniejszym opracowaniu jest problematyka reklamy naruszającej uczucia religijne na gruncie polskiego systemu prawnego. Niemniej jednak, jedynie dygresyjnie warto wspomnieć o istotnym przypadku reklamy wywołującej kontrowersje w zakresie obrazy uczuć religijnych, jaki miał miejsce na Litwie, a który zakończył się rozstrzygnięciem Trybunału w Strasburgu. Otóż w przedmiotowym przypadku w reklamie występowała postać Jezusa oraz Maryi reklamujących odzież z dopiskami - „Jezu, jakie spodnie”, „Matko święta, co za sukienka". Litwiński odpowiednik Urzędu Ochrony Konkurencji i Konsumentów uznał przedmiotową reklamę za obrażającą uczucia religijne. Marka nie zgodziła się jednak z przytoczonym stanowiskiem, składając skargę do Europejskiego Trybunału Praw Człowieka. Trybunał nie zgodził się z argumentacją litewskiego organu, wskazując, iż samo ukazanie postaci Jezusa oraz Maryi w połączeniu z przytoczonymi powyżej dopiskami

\footnotetext{
${ }^{16}$ Organ Rady Reklamy powstałej w celu stworzenia, promocji i ochrony zasad, jakimi powinni kierować się przedsiębiorcy zajmujący się działalnością reklamową na terytorium Rzeczypospolitej Polskiej oraz polscy przedsiębiorcy reklamujący się za granicą tzw. samoregulacja reklamy, zob. https://radareklamy.pl/ [dostęp: 04.07.2021].

${ }^{17}$ Uchwała Komisji Reklamy Nr ZO 83/15 z dnia 18 czerwca 2015 r. Zespołu Orzekającego w sprawie sygn. akt K/28/15.
} 
nie stanowi obrazy uczuć religijnych [Warecka 2018]. Gdyby opisany powyżej przypadek analizować z wykorzystaniem polskiej regulacji prawnej, warto zauważyć, że na tle art. $196 \mathrm{KK}$ ocena, czy doszło w przywołanej reklamie do obrazy uczuć religijnych mogłaby nastręczać pewnych trudności ze względu na rozbieżność $\mathrm{w}$ doktrynie co do pojmowania przedmiotu czci religijnej. Zasadnym jednak wydaje się uznać, iż przytoczona wyżej reklama nie obraża uczuć religijnych, abstrahując bowiem od ukazania podmiotu kultu, choć w art. 196 KK mowa o przedmiocie bądź miejscu, to w reklamie tej nie użyto wulgarnego języka ani też nie ukazano religijnych postaci w sposób znieważający. Nie zmienia to jednak faktu, iż dla osób wierzących owa reklama może wzbudzać pewien dyskomfort moralny.

\section{WNIOSKI}

Wykreowanie uniwersalnej definicji reklamy, jak również zbadanie pojęcia obrazy uczuć religijnych wraz ze wskazaniem jego desygnatów, pozwoliło na przeanalizowanie realnych możliwości naruszenia art. $196 \mathrm{KK}$ poprzez reklamę. Przeprowadzona analiza pozwala na udzielnie jednoznacznie twierdzącej odpowiedzi na pytanie postawione w niniejszym artykule. Za powyższym przemawia stanowisko doktryny, jak i orzecznictwa, co ukazano w powyższych rozważaniach, bowiem reklama ze względu na jej publiczny charakter, jak i nieograniczoną formę daje możliwość spełnienia części przesłanek wynikających z treści art. $196 \mathrm{KK}$.

To, co jednak wyraźnie się ukazuje po analizie pojęcia reklamy na tle regulacji zawartej $\mathrm{w}$ art. $196 \mathrm{KK}$, to fakt, iż regulacja ta pod względem literalnym jest dość wąska, bowiem wskazuje na możliwość obrazy uczuć religijnych poprzez znieważanie miejsca bądź przedmiotu o charakterze religijnym. I choć $\mathrm{w}$ doktrynie pojawiają się dwa różne stanowiska odnośnie do pojmowania przedmiotu czci religijnej, to jednak zdaniem autora bardziej zasadne wydaje się stanowisko, zgodnie z którym przedmiot czci religijnej należy interpretować czysto materialnie. Takie rozumienie art. 196 KK wyłącza możliwość zastosowania przedmiotowej regulacji, kiedy w reklamie pojawia się bóstwo, nawet gdy jego obraz jest obraźliwy. Być może zasadne wydałoby się poszerzenie tej regulacji o sferę podmiotowości, tak ażeby nie budziło to wątpliwości zarówno na gruncie doktryny, jak i orzecznictwa. Uczucia religijne same w sobie są czymś, czego nie da się 
w sposób dostatecznie ostry zdefiniować, nie da się też wyznaczyć ich granic, a przecież sama religia to nie tylko miejsca czy przedmioty kultu, to też idea, czy postacie, które się w danej religii pojawiają. Dla osoby wierzącej równie obraźliwe może być ukazanie w niestosowny sposób przedmiotu kultu, co bóstwa czy Boga danej religii. Fakt, iż w doktrynie pojawia się rozdźwięk co do zakresu możliwości zastosowania omawianego artykułu, poszerzenie jego treści o wyraźne wskazanie również na obrazę podmiotów czci religijnej w znaczący sposób ułatwiłoby jego interpretację i tym samym pozwoliłoby ujednolicić stanowisko doktryny.

Powyższe nie zaprzecza jednak możliwości dopuszczenia się przestępstwa obrazy uczuć religijnych w reklamie. $\mathrm{Z}$ całą pewnością reklamy dotykające sfer duchowości czy wiary przez osoby wierzące będą odbierane jako kontrowersyjne, należy jednak pamiętać, że ocenie obrazy uczuć powinien przyświecać pełen obiektywizm. Wspomniany obiektywizm nie powinien jednak stać $\mathrm{w}$ sprzeczności $\mathrm{z}$ wartościami reprezentowanymi przez daną grupę religijną.

\section{PIŚMIENNICTWO}

Budyn-Kulik, Magdalena. 2014. „Znieważenie uczuć religijnych - analiza dogmatyczna i praktyka ścigania.” Prawo w działaniu. Sprawy karne 19:100-37.

Cebula, Sławomir. 2012. „Obraza uczuć religịnych, czyli kontrowersje wokół artykułu 196 kodeksu karnego.” Studia Religiologica 45, nr 5:294-300.

Czepita, Stanisław, i Łukasz Pohl. 2012. „Strona podmiotowa przestepstwa obrazy uczuć religijnych i jego formalny charakter.” Prokuratura i Prawo 12:72-82.

Filar, Marian, i Marcin Berent. 2016. „Komentarz do art. 196.” W Kodeks karny. Komentarz, wyd. 5, red. Marian Filar. Warszawa: Wolters Kluwer Polska. Legalis.

Grębowiec, Mariusz. 2010. „Reklamy kontrowersyjne i ich wpływ na podejmowanie decyzji nabywczych przez konsumentów.” Zeszyty Naukowe Polityki Europejskie, Finanse i Marketing 52, nr 3:444-55.

Hypś Sławomir. 2021. „Komentarz do art. 196.” W Kodeks karny. Komentarz, wyd. 7, red. Alicja Grześkowiak, i Krzysztof Wiak. Warszawa: Wydawnictwo C.H. Beck.

Karpiuk, Mirosław, i Katarzyna Chałubińska-Jentkiewicz. 2015. Prawo nowych technologii. Wybrane zagadnienia. Warszawa. Wolters Kluwer Polska.

Kozłowska-Kalisz, Patrycia. 2015. „Komentarz do art. 196.” W Kodeks karny. Komentarz, wyd. 7, red. Marek Mozgawa. Warszawa: Wolters Kluwer Polska. Lex.

Mądry, Mateusz. 2016. „Pojęcie reklamy na gruncie ustaw mających uniwersalne zastosowanie." W Instytucie rynku farmaceutycznego, red. Rafał Stankiewicz. Warszawa: Wolters Kluwer Polska. Lex. 
Modrzeiewska, Małgorzata. 2020. „Umowy w sferze marketing i reklamy.” W System Prawa Handlowego. T. 5b: Prawo umów handlowych, red. Mirosław Stec. Warszawa: Wydawnictwo C.H. Beck. Legalis.

Namysłowska, Monika. 2007. „Nowa ustawa o przeciwdziałaniu nieuczciwym praktykom rynkowym." Monitor Prawniczy 23:1287-292.

Niewęłowski, Adrian, red. 2021. „Komentarz do art. 4.” W Adrian Niewęgłowski, Ustawa o radiofonii i telewizji. Komentarz. Warszawa: Wolters Kluwer Polska. Lex.

Nowińska, Ewa. 2005. „Reklama, sponsoring, telesprzedaż, lokowanie produktu.” W Prawo mediów, red. Ryszard Markiewicz. Warszawa: LexisNexis. Lex.

Piórkowska-Flieger, Joanna. 2016. „Komentarz do art. 196.” W Kodeks karny. Komentarz, wyd. 7, red. Tadeusz Bojarski. Warszawa: Wolters Kluwer Polska. Lex.

Starzyńska, Katarzyna. 2015. „Charakterystyka reklamy w oparciu o jej geneze i cechy." Zeszyty Naukowe Uniwersytetu Przyrodniczo-Humanistycznego w Siedlcach. Seria: Administracja i Zarzadzanie 106:275-81.

Ślęzak, Piotr. 2011. Reklama jako czyn nieuczciwej konkurencji. Katowice: Wydawnictwo Uniwersytetu Śląskiego.

Tryka, Barbara. 2017. „Zagadnienie uczuć religijnych w kontekście artykułu 196 kodeksu karnego." Analiza i Egzystencja 40:67-93.

Walczak, Ryszard. 2001. „Wyrok SN z 26 stycznia 2006 r., V CSK 83/05.” W Prawne aspekty reklamy $w$ ustawodawstwie polskim, europejskim $i$ międzynarodowym. Orzecznictwo, 551-60. Wrocław-Poznań: LexPolonica.

Warecka, Katarzyna. 2018. „Strasburg: Jezus i Maria mogą występować w kampaniach reklamowych. Sekmadienis Ltd. przeciwko Litwie - wyrok ETPC z dnia 30 stycznia 2018 r., skarga nr 69317/14.” Lex.

Wiewiórowska-Domagalska, Aneta, i Aleksandra Kunkiel-Kryńska. 2019. „Komentarz do art. 2." W Ustawa o przeciwdziałaniu nieuczciwym praktykom rynkowym. Komentarz, red. Konrad Osajda. Warszawa: Wydawnictwo C.H. Beck. Legalis.

Wiszniewska, Joanna. 2019. Zakaz reklamy aptek i ich działalności. Warszawa: Wydawnictwo C.H. Beck.

Zgoliński, Igor. 2020. „Komentarz do art. 196.” W Kodeks karny. Komentarz, wyd. 3, red. Violetta Konarska-Wrzosek. Warszawa: Wolters Kluwer Polska. Lex.

\title{
Reklama a obraza uczuć religijnych
}

\begin{abstract}
Abstrakt
Reklama na dobre wpisała się w otoczenie, stała się nieodzownym elementem codziennego funkcjonowania. Przybiera rozmaite formy, od reklamy telewizyjnej, przez radiową, po reklamy prasowe. Przedsiębiorcy prześcigają się w skupieniu uwagi jak najszerszego grona potencjalnych klientów. Niepohamowany rozwój konkurencji przesuwa granice - coraz więcej sfer życia zostaje wykorzystywanych w spotach reklamowych. Jedną z takich sfer, do jakich niejednokrotnie odwoływała się reklama, jest sfera duchowości i wiary. W niniejszym opracowaniu uwaga została skupiona na rozważaniach dotyczących reklamy w odniesieniu do obrazy uczuć religijnych. W pier-
\end{abstract}


wszej kolejności zostały zdefiniowane pojęcia reklamy i obrazy uczuć religijnych. Następnie przeanalizowana została możliwość obrazy uczuć religijnych poprzez reklamę. Aby uzupełnić całość i nadać opracowaniu praktyczny wydźwięk, autor uzupełnił tę analizę przykładami reklam odnoszących się do sfery duchowości i ocenił je pod kątem obrazy uczuć religijnych.

Słowa kluczowe: reklama; uczucia religijne; obraza uczuć religijnych; konsument

\title{
Advertising and Offending Religious Feelings
}

\begin{abstract}
Advertising - it has become a part of the environment, it has become an indispensable element of everyday functioning. It takes various forms, from television advertising, through radio advertising, to press advertising. Entrepreneurs compete in focusing the attention of the widest possible group of potential customers. The unloved development of competition is pushing the boundaries - more and more spheres of life are used in advertising spots. One of the spheres that the advertisement has repeatedly referred to is that of spirituality and faith. In this paper, the focus will be on the consideration of advertising in relation to offending religious feelings. First, the concepts of advertising and images of religious feelings were defined. Then the possibility of offending religious feelings through advertising was analyzed. In order to complete the whole and give the study a practical meaning, the author supplemented this analysis with examples of advertisements related to the sphere of spirituality and assessed them in terms of images of religious feelings.
\end{abstract}

Keywords: advertising; religious feelings; insulting religious feelings; consumer

Information about Author: WeroniKa WoŹNA-BURDZIAK, MA - Ph.D. student, Faculty of Law and Administration, University of Szczecin; correspondence address: ul. Narutowicza 17A, 70-240 Szczecin, Poland; e-mail: weronika.woznaburdziak@usz.edu.pl; https://orcid.org/0000-0002-1271-6028 